\title{
POOR BEHAVIOR OF BEGGARS IN CIREBON CITY
}

\author{
Halim Purnomo ${ }^{1}$, Dianasari ${ }^{1}$ \\ ${ }^{1}$ The Faculty of Teacher Training and Education Program University of Muhammadiyah Cirebon, West Java, Indonesia \\ Correspending Email: Halim_purnomo@yahoo.co.id, diana@gmail.com
}

\section{Article history}

Received:14/09/2015
Received in revised form:14/09/2015
Accepted: 18/10/2015

\begin{abstract}
This study wants to prove that the higher the spiritualists among beggars, can control the behavior of poor. Conversely, the lower the spiritualist, the higher the poor behavior. Research shows that most of the beggars claim that they are doing maghdhah obligation was limited to abort an obligation. Scores of worship are not applied at all in life is evidenced with no effort and creativity to break out of the circle begging. Rather, they use it to meet all the needs of his family. Begging activities they run has been planned from the start to dress in such a way that completely seedy carrying children there is even a temple temples disabilities. Some beggars who have experienced demolition of the Civil Service Police Unit and the fostering of Social Services and Man Power Cirebon was not influenced by the existence of them run the routine on the streets. Conclusion and this research is begging activity has been used as a new profession. This has been recognized by their income that they get from the requesting this allows them to get out of any economic slump family and reluctant to get out of this habit.
\end{abstract}

Keywords: poor behavior, beggars, Cirebon City. 


\subsection{INTRODUCTION}

The Cirebon city has long been known as the Wali Town, as has historically been the center of the spread of Islam in West Java in particular, and the land of Java in general. Development of Cirebon City as a city guardian who is supported by the historical fact of the proclamation of the Islamic empire began first by Sheikh Sharif Hidayatullah who holds Sunan Gunung Jati, he is members of Wali Sanga (9 Wali) as a propagator of Islam in Indonesia.

Cirebon as Wali Town being born from a struggle of Sinuhun Gunung Jati who had the courage to escape from the reign of King Hindu Padjajaran that had a title Prabu Siliwangi, which is none other than his own grandfather. Proclamation of the Islamic empire that is the birth of Cirebon momentum as the Wali Town, when headed by a Wali (Sunan Gunung Jati).

Regardless of the vision and mission of Cirebon City as the politically trade and services empirically, Cirebon City position as a Wali Town historically can not be overlooked. Therefore, anyone who became head of the region, regent or mayor in Cirebon, he can not be separated from the will of Sinuhun Sunan Gunung Jati as the founder of the first Islamic kingdom in West Java.

The appearance and behavior of the leader of Cirebon is the appearance of a "mayor" who always tawaddu and committed to religious teachings, behave according to the norms and values of Islam and the activities and programs developed in harmony leads to the welfare of emotional and physical, earthly and hereafter, material and spiritual. One of the message he was simple and modest "ingsun titip tajug lan fakir miskin" (I just leave the mosque and the poor), should always be a reference in the development policies entrusted the mosque and the poor is a symbol religion testament should be practiced, so that people Cirebon become a society of religious, obedient, his heart is always connected with prosperity mosque so avoid the ills of society.

Community of beggars in the Cirebon city interpret surrogate Sinuhun Sunan Gunung Jati as an opportunity to earn a fortune from society in Cirebon who have spiritual ties built by Sinuhun Sunan Gunung Jati. Facts and reality of society Cirebon especially road users will be very easy to watch our brothers and sisters whose fate "disadvantaged", both from the psychological and social aspects that depend to expect mercy. Because almost all intersections in the Cirebon city filled by beggars and buskers, in general they run their activities along the corner of the city, especially of each intersection is considered very strategic to be used to collect forgive-powder of precious stones coins from the pegendara especially when traffic light shows red light lit.

Models of applicants was indeed very diserve. There are really sick, sudden illness or malingering, which is really sick as an example they show her legs really stump (broke one of his legs due to accidents or congenital born), carrying a stick for those who are blind are guided by the "aide". As for the malingering no one beggar at the intersection of Jl. Dr. Cipto Mangunkusumo and Jl. Kesambi that tuck one of his foot with covered pants kombrangnya (pants model width) so impressed defective real, some are using the media of cotton soaked with liquid Betadine (iodine) and then placed in one of his legs which didikat with bandages neatly so impressed really sick. Jabir Hasan Khan, Menka (2013) said "The causes of Urban have become beggars in the Aligarh district almost entirely due to social and economic problems."

\subsection{ACADEMIC DEBATE}

Social or psychological scientists have different views related to the cause of the presence of beggars. There are some who believe that the existence of beggars due to the economic problems of disadvantaged (economic inequality). While others argue that the proliferation of beggars in various regions is mainly due to lack of spirituality. Here some leaders involved in the debate:

\subsection{Figures who agreed economic issues}

Khan, Menka JH (2013) argued about cause of The Urban have become beggars in the Aligarh district almost entirely due to social and economic problems. Humans often assume that money is everything to achieve "prosperity" as recounted.Adi Surya P., argued mental beggars and manipulative behavior is not only happening in grass roots. This republic even had to be admitted to the poor in order to get a debt from the IMF. Fell in the image "economic difficulty" to attract pity donor countries to send aid. Culture poor showing cultural elements commonly found among poor people in society are different, 
he focused on the culture of default which behavior patterns and special values, this pattern does not shape the culture, but rather form a variation national culture as a sub-culture.

According to someone who earn a living from begging in various ways and reasons used in order to expect compassion and generosity of others. They are also an individual or group of people who take advantage of shortage of social circumstances with hope the mercy of others. The very basic reason relating to the proliferation of beggars is their inability to adapt to the times that is because they always stand by twelve expect pity from others.

Helen K. Black and Ernest Mandel found the outbreak of beggars because of the encouragement the community where they are joined.Chriswardani Suryawati argued that poverty is more often associated with the economy because of the dimensions is the most easily measured and observed and compared, whereas poverty is also closely related to social, political, cultural, health, education, religious and moral. Furthermore, he said that poverty reduction strategies should not be fixated on the economic aspect and the physical, but the non-physical aspects (spirituality) also need to get a sufficient portion in this policy. So that the religious and moral education is very important for the cultivation of religious values and character, especially for children and youth.

\subsection{The figures agreed for the issue of spirituality.}

David Aldridge (1993) argued that the outbreak of beggars due to factors understanding and practice of religion is not balanced.In the religious view of Islam, the main emphasis is generally present in the repertoire of allegiance to the beauty of the spiritual, moral and mental. But the most obvious, the physical dimensions of life also contribute to fulfill it, of course, controlled by the moral and spiritual values. People who are not spiritually driven up to the level of spiritual slowness. While people who have a high spirituality and religiosity will be able to feel the essence of a "health".

Helen K. Black (1999) argued that people underestimate the rise of social values caused because they lack self-awareness of responsibility towards God. Someone who has a high spirituality can find the meaning of his life both in his personal life and in relationships. Even according to the spiritual world is a journey of self to discover the truth and regarded as a medium for connectedness with God. According to the flow of Humanistic psychology, said that humans have an awareness of the potential of the so-called Altered states of consiousnes to reach spirituality world area.

Al Ghazali in Muhammad Zaki Mubaraq (tt. It. 113) sighted that a person is difficult to free himself from his bonds. Because the impact it makes the soul addiction, or a tendency to repeat.Someone who has a high spirituality can find the meaning of his life both in his personal life and in relationships. Even according to the spiritual world is a journey of self to discover the truth and regarded as a medium for connectedness with God. According to the flow of Humanistic psychology, said that humans have an awareness of the potential of the so-called Altered states of consiousnes that can reach spirituality world area.

\subsection{People who support both.}

Marx in Peter Beilharz (2002) view that the economy is the determinant of the most influential institutions of the society, while ideology, belief, culture, law, language and religion respectively connote only if it is associated with the economy. Humans when faced with problems, apart because of factors such needs, people often only emphasizes the interpretation of rationality, logic and objectivity without thinking intervention of God as a reference that should be taken into consideration. Moreover, humans assume that money is everything to achieve "prosperity" as recounted in the novel of Michael Ende, Momo, when human looking for money as much as the public shows that cold, dead and stiff. Money is concrete, but happiness is abstract. Therefore, it is not possible if the two are related directly. Thus, people become familiar with the material, but foreign to him. He was just leaning on things outside themselves, focusing on nothing in front of him, then left his inner emptiness.

Althusser Peter Beilharz argued that the economy as a problem, but not in practice and ideology and consensus that can form konducive society. Spirituality is closely associated with psychological dimensions, psychological and social dimensions. Spiritual experience provides an impetus and energy in themselves to continue to connect with something meaningful. 


\subsection{SUBJECTS AND OBJECTS RESEARCH}

The subjects in this study were the beggars in the Cirebon who runs the activity of begging andaround begging in residential areas.

The object of this research is the spirituality and the poor behavior of beggars in Cirebon.

\subsection{RESULTS}

The beggars work to meet basic needs or satisfy the interests of others by begging or asking for help from others, especially to users of the road. In homogeneous, the beggars will look at the environment dynamically in giving the meaning of friends, intimate friends (either similar or different types), and an enemy to be resisted. They found the interaction with the patterns of friendship, rivalry, even hostility in order to obtain material possession, appreciation, respect and appreciation of their peers in their respective environments.

The beggars are competing individual figure among the community in fulfilling its interests. From the age they are very diverse, smaller and vulnerable they are dealing with the senior beggar who have "plenty to eat salt". Paced hard road conditions have shaped the character and behavior and their perspective on the issues, and they have different experiences with the families that live in a family environment or standards.

Open the eyes of the phenomenon of beggars would raise awareness on the issue. Do not merely look and then give a dime when they roam, but their existence through research reconstruction more important. As long as shockingly this is admittedly difficult to reduce the number of them, in addition to the limitations of the seriousness of the government is also due to weak solutions are built in order to minimize and even eliminate community beggar.

According to researchers, the poor behavior which now bears caused by habits that have lived for many years and apathy of the family. Thus, in a review of psychological him down except by begging. Furthermore beggars have dynamic characteristics. Dynamic characteristics regarding their mobility from one location to another locations. This mobility will demonstrate their behavior in everyday life, both among the community and his family.

If we look from the characteristics of the individual, then the habit of beggar just for spree, as evidenced by his bad habit that collect the coffers of the rupiah is not just to make ends meet but for spree. This is an indication that the person concerned is sufficient in terms of money, but that makes them always begging due to poor behavior. Meaning the role of self beggars in the Cirebon City in the way they see themselves, mostly in its environment as it is known that begging is a choice that must be taken in an effort to answer the family's economic problems. Most of them take their children ranging from infant to children as young as elementary school. The reason to take their children apart to increase public sympathy also to supplement their income.

In a psychological review this habit will be able to imprint their children to earn money that does not need to laboriously only with heat on the streets. They also indicate the absence of creative effort to get out of the slump psychologically, that is precisely they are apathetic towards any community assessment form posted to them. The most important for them is that have shaped his personality adequacy of the results of compassion and pity of others. Indeed this behavior has made an impression on the perspective and their lifestyle.Both individually or in a team, beggars would have tried to portray himself as what they want. On the other hand, interaction and behavior of beggar between them either beggars or not a beggar was built by a distinctive symbols and the meaning of its own. Subjectively beggars creating symbols that can be used to interact with fellow beggars in the social system and their psychological. 


\section{References}

Adi Surya P, BidangHukumdan HAM DPD KNPI Kab. Sumedang Ketua DPC GMNI Sumedang.

Catatan Departemen Sosial RI Tahun 2002.

Chriswardani Suryawati, “'Memahami Kmiskinan Secara Multidimensional.” Jurnal Fakultas Kesehatan Masyarakat dan Magister Ilmu Kesehatan Masyarakat Universitas Diponegoro, JMPK Vol. 08/No.03/September/2005.

Helen K. Black, “' Poverty and Prayer': Spiritual Narratives of Elderly African-American Women.” Review of Religious Research, Vol. 40, No. 4 (Jun., 1999), pp. 359-374

Khan, J. H. Menka, "'Regional Analysys of Literacy Rate and Socio-Economic Development of Urban Beggars in Aligarh District." Pranjana 16, no. 1 (2013): 46-55.

Mubaraq, Muhammad Zaki, al-Akhla $>q$ 'inda al-Gaza>li (Maktabah Tijariah al-Kubra), tanpa tahun, hal. 113.

Mukharjee R. Causes of beggary. In J. M. Kumarappa (ed) Our Beggar Problem: How To Tackle It (1945), pp. 19-26. Bombay: Padma Publications Ltd.

Peter Beilharz, Teori-TeoriSosial.ObservasiKritisTerhadap Para FilosofTerkemuka(Yogyakarta; PustakaPelajar, 2002), hal. 2.

Published by:Religious Research Association, Inc._Stable URL:http://www.jstor.org/stable/3512122. Accessed: 27/10/2014 02:01

Stephen, Hawking.The Grand Design: Rancang Agung. Edisi Bahasa Indonesia terjemahan Zia Anshor(Jakarta: PT. Gramedia Pustaka Utama, 2002).

Yasmin Kartika Sari, “'Alam, Manusia dan Spiritualitas”. Jurnal Sosiotekhnologi (2011), edisi 4.

Muhammad Fadhlu rahman Ansari, The Qur'anic Foundations and Structure of Moslem Society, (alih bahasa) (Bandung: Risalah Bandung, 1983), 135.

Peter McGhee \&Patricia Grant, "'Spirituality and Ethical Behaviour in the Workplace: Wishful Thinking or Authentic Reality." EJBO Electronic Journal of Business Ethics and Organization StudiesVol. 13, No. 2 (2008). 